BIOMEDICAL AND BIOSOCIAL ANTHROPOLOGY
$\begin{gathered}\text { Official Journal of the International Academy } \\ \text { of Integrative Anthropology } \\ \text { journal homepage: http://bba-journal.com }\end{gathered}$

\title{
The impact of glenoid labrum damages on condition of the cartilage of the shoulder joint
}

Strafun S.S. ${ }^{1}$, Sergienko R.A. ${ }^{2}$

${ }^{1} \mathrm{SI}$ "Institute of traumatology and orthopedics AMS of Ukraine", Kyiv, Ukraine 2MC "Modern orthopedic", Kyiv, Ukraine

\section{ARTICLE INFO}

Received: 1 Aprile 2019

Accepted: 11 May 2019

UDC: $616.727 .2-018.3-001.3-07$

\section{CORRESPONDING AUTHOR}

e-mail: ruslan.sergienko.md@gmail.com Serghiyenko R.O.

\begin{abstract}
The joint labrum is an anatomical structure of the shoulder joint, one of the functions of which is to ensure the stability of the shoulder. It has been proven that instability, direct trauma and surgery of any joint eventually lead to cartilage damage and osteoarthritis. It is still unknown whether and how the damage to the joint labrum affect the condition of the cartilage of the shoulder joint. Aim of study - investigation of impact of glenoid labrum damages on condition of the cartilage of the shoulder joint. For the period from 2006 to 2016, on the basis of State Institution "Institute of Traumatology and Orthopedics of AMS of Ukraine", MC "Modern Orthopedics", Kyiv, a study was conducted on an array of 467 patients. Used clinical diagnostics, MRI diagnostics, arthroscopic diagnostics. Fact verification and localization of joint damage was performed during arthroscopic examination. Localization of cartilage damage was divided into separate areas on the articular surfaces of the shoulder scapula and head. The degree of cartilage damage was classified by Outerbridge. Quantitative analysis of the results was performed using Microsoft Excel in the summary tables. It has been found that damage to the shoulder labrum is the cause of cartilage defects in the joint surfaces of the shoulder. The incidence and severity of cartilage defects increase over time since the injury. The worst prognosis for the development of damage to the articular cartilage is characteristic of patients with damage to the posterior part of the labrum. Thus, damage to the joint labrum is a significant factor in the occurrence of defects in the articular cartilage of the shoulder. Early active surgical tactics for the treatment of damage to the joint labrum are necessary to prevent deterioration of the condition of the joint surfaces and the prevention of osteoarthrosis.

Keywords: shoulder joint, shoulder labrum, cartilage defects of shoulder joint.
\end{abstract}

\section{Introduction}

The joint labrum $(\mathrm{JL})$ is an anatomical structure of the glenohumeral joint, and one of the functions of which is to ensure the stability of the shoulder [16]. It is a well-known fact that damage to the $\mathrm{JL}$ leads to the development of instability of the glenohumeral joint, up to the occurrence of habitual dislocations [7, 23]. Attention should be paid to surgical treatment in the event of JL injury, in order to prevent the development of instability and habitual dislocation of the shoulder. Patients are informed that the surgical treatment of $\mathrm{JL}$ damage is important for restoring the stability of the shoulder joint and restoring its functional. On the other hand, the issue of treatment of $\mathrm{JL}$ damage as a way of preventing articular cartilage damage and the development of osteoarthritis is not considered at all. In the available literature, studies of the effect of $\mathrm{JL}$ damage on the condition of the glenohumeral joint cartilage have not been identified. Although it is well known that instability, direct trauma and surgery of any joint eventually lead to cartilage damage and osteoarthritis [7]. And if cartilage damage in the knee or hip joint manifest early enough, then clinical manifestations of damage to the cartilage of the glenohumeral joint are noted in only 5 to $17 \%$ of cases $[6,14,17]$. That is, the overwhelming number of patients with cartilage damage have no clinical manifestations, respectively, are not treated and are direct candidates for the development of shoulder osteoarthritis (SOA). If we had information about whether and how the damage of the $\mathrm{JL}$ influences the condition of the cartilage of the glenohumeral joint, we would know about the need or no need for prevention of SOA in such patients. We still do not have 


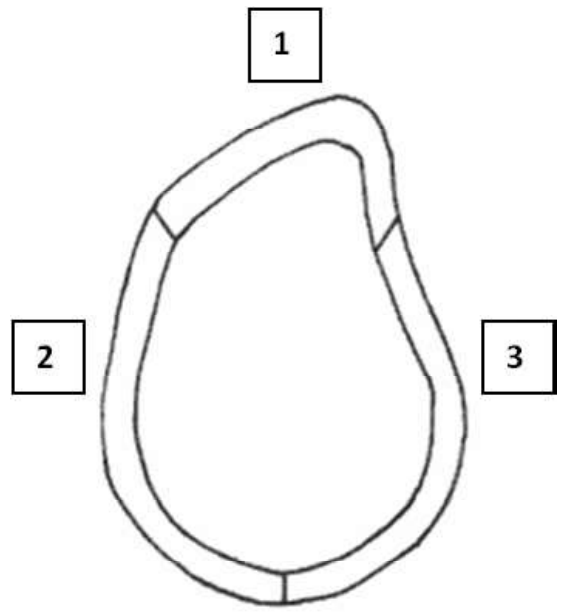

Fig. 1. The glenoid cavity of the right scapula presented schematically in lateral position. $\mathrm{JL}$ is conditionally divided into upper (1), rear (2), front (3).

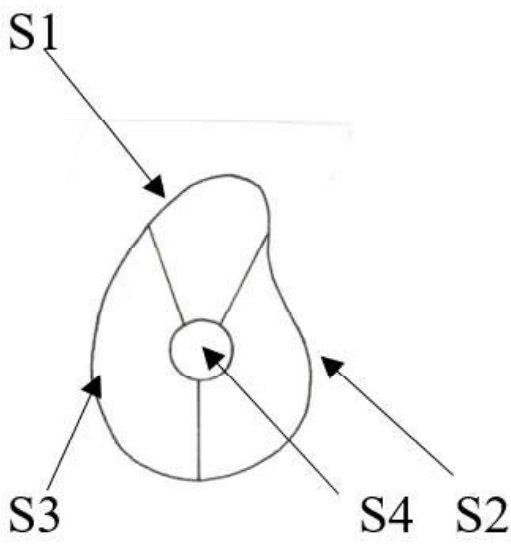

Fig. 2. The division into the areas of the glenoid cavity (according to the boundaries of the mounting $\mathrm{JL}+$ anatomical center of the glenoid cavity). such knowledge. The following study was conducted to find out the effect of glenohumeral JL injury on the cartilage of the articular surfaces.

The purpose of the work is to determine the effect of shoulder $\mathrm{JL}$ damage on the condition of the cartilage of the glenohumeral joint.

\section{Materials and methods}

For the period from 2006 to 2016, on the basis of State Institution "Institute of Traumatology and Orthopedics of AMS of Ukraine", MC "Modern Orthopedics", Kyiv, a study was conducted on an array of 467 patients. Used clinical diagnostics, MRI diagnostics, arthroscopic diagnostics.

Verification of the fact and localization of the damage to the joint labrum were performed during arthroscopic examination. Damage to the $\mathrm{JL}$ was considered complete periosteal separation. The $\mathrm{JL}$ sections were separated as follows (Fig. 1).

Damage to the upper $\mathrm{JL}$ with distribution to part of the front and/or posterior $\mathrm{JL}$ was considered to be damage to the upper JL. Total damage to the $\mathrm{JL}$ was considered to be a tear-off at the perimeter of the scapula with no intact areas. Patients with damage to different areas of the $\mathrm{JL}$ were not included in the study.

Damage to the cartilage of the glenoid cavity was zoned as follows (Fig. 2).

The conditional distribution of the articular surface of the humeral head was performed as follows (Fig. 3).

The degree of cartilage damage was classified by Outerbridge [15].

Quantitative analysis of the results was performed using Microsoft Excel in the summary tables.

\section{Results}

The distribution by gender and age of patients is presented in Figure 4.

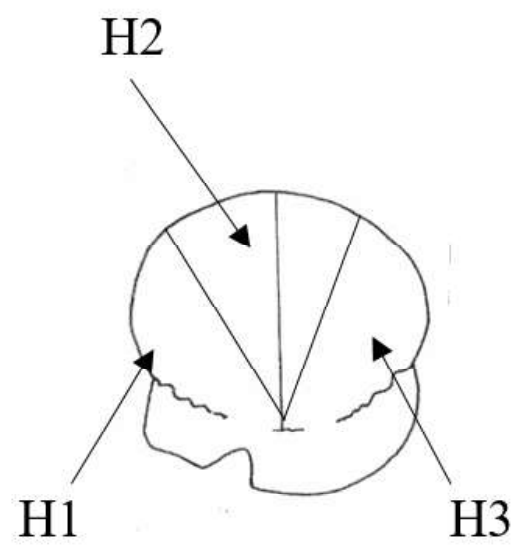

Fig. 3. The articular surface of the left humeral head presented schematic, top view.

As can be seen from the diagram (see Figure 4), the majority $(65 \%)$ were young men. In general, the gap in the number of cases of $\mathrm{JL}$ injury between men and women is large in the patient population of less than 50 years. However, in the group of patients older than 50 years, this gap is narrowing, and in the group of patients older than 60 years, women with $\mathrm{JL}$ damage occur more than men. This can be explained by the relative decline in physical activity in men over 50 , as well as the prevailing number of women in the population over 60 dues to their longer life expectancy.

The distribution of $\mathrm{JL}$ damage by localization is indicated in Table 1.

As can be seen from the data in Table 1, the patients are dominated by damage to the front and top of the $\mathrm{JL}$.

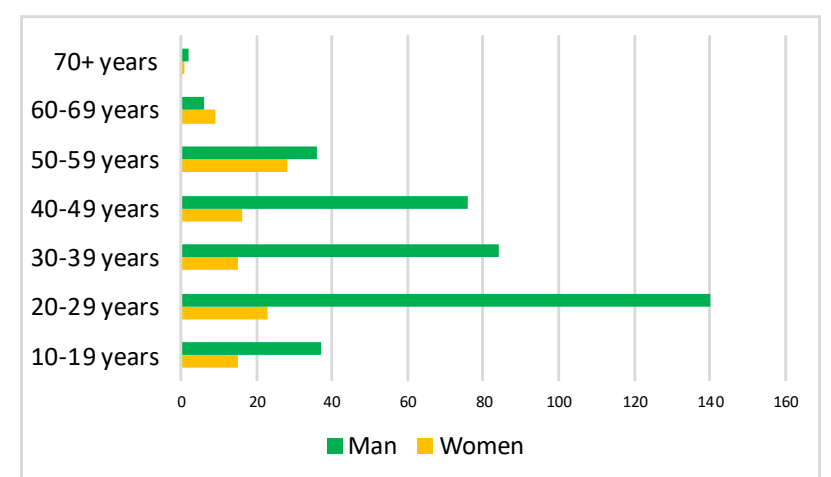

Fig. 4. Distribution of patients by age and sex.

Table 1. Distribution of JL damage by localization.

\begin{tabular}{|c|c|c|}
\hline Localization of JL damage & $\begin{array}{c}\text { Number of } \\
\text { patients }\end{array}$ & $\begin{array}{c}\text { Percentage of total } \\
\text { cases }(\mathrm{n}=467)\end{array}$ \\
\hline $\begin{array}{c}\text { Total damage (eliminated due to } \\
\text { insufficient number of cases) }\end{array}$ & 1 & 0.2 \\
\hline Front JL & 200 & 42.8 \\
\hline Upper JL & 237 & 50.7 \\
\hline Rear JL & 29 & 6.2 \\
\hline
\end{tabular}




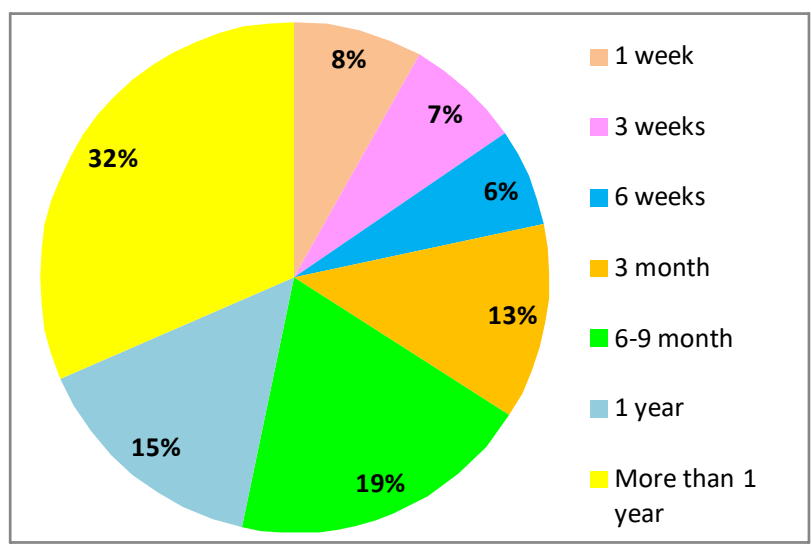

Fig. 5. The time between trauma and surgery.
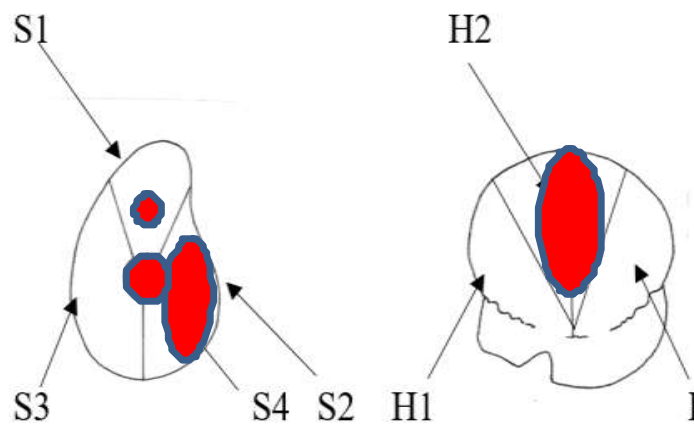

ig. 6. Localization of defects of the articular surfaces in case of damage to the upper part of the JL.
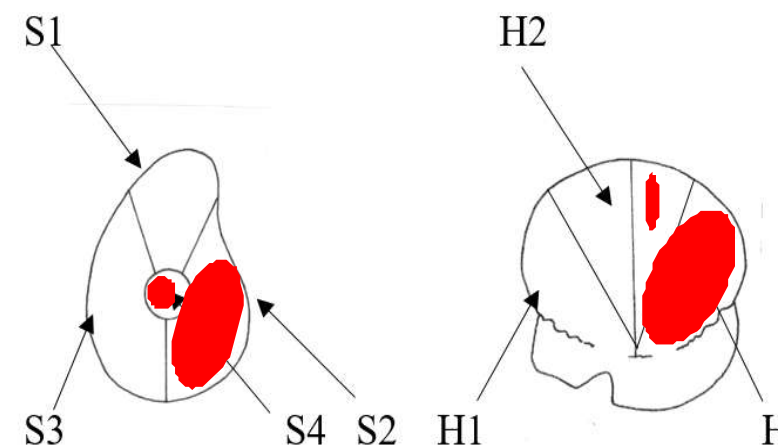

Fig. 7. Localization of defects of the articular surfaces in case of damage to the anterior part of the $\mathrm{JL}$.
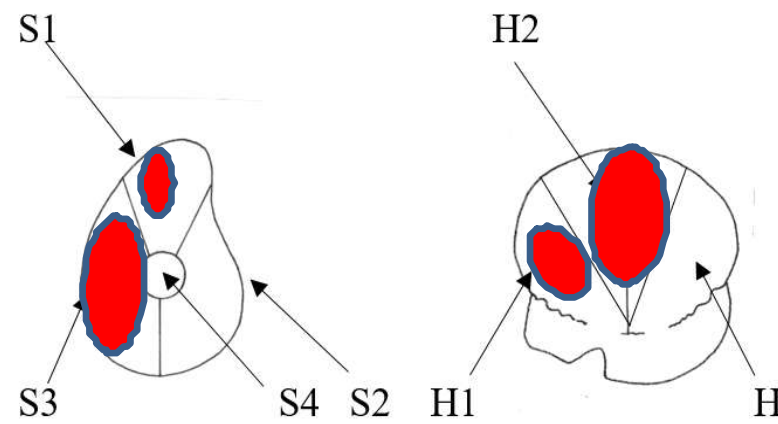

Fig. 8. Localization of defects in articular surfaces with damage of the back part of the JL.
Damage to the rear part of the $\mathrm{JL}$ is rarer. This fact can be explained by the fact that the movements in the shoulder joint complex occur mainly in the anterior hemisphere of the space, whereas the posterior half of the space is rarely used in daily activities.

It was found that almost half of the patients were operated on a year or more after the injury, and in the first 6 weeks, only one in five (Fig. 5).

More than $68 \%$ of patients had damage to the glenoid cavity cartilage and humeral head of varying severity. In the group of patients with a detachment of the upper part of the $\mathrm{JL}$ in $64 \%$ of cases the cartilage damage of the glenoid cavity was found and in $28 \%$ of patients the cartilage of the humeral head was damaged. In the group of patients with damage to the anterior part of the $\mathrm{JL}$, respectively, $62 \%$ and $48 \%$. In the group of patients with damage to the back of the $\mathrm{JL}$, respectively $67 \%$ and $81 \%$. These data indicate that the damage of the posterior $\mathrm{JL}$ is the most aggressive pathology in terms of chondral damage to the articular surfaces. It should also be noted that the articular cartilage of the shoulder blade suffers approximately equally in all groups. That is, for cartilage of the glenoid cavity, damage to the $\mathrm{JL}$ is a more aggressive factor in the development of further damage. This can be explained by the fact that the humeral head loads different parts of the joint surface during the change of rotational position of the humerus, and the contact areas of the articular surface of the shoulder blade are unchanged. This may also be due to the fact that the articular cavity of the scapula is covered with fibrous cartilage and the head is hyaline [16].

Let's look at where the defects were localized when the upper part of the JL was damaged. As can be seen from Figure 6, the accompanying cartilage lesions on the scapula were located predominantly in segments S2, S4, and on the articular surface of the humeral head in $100 \%$ of cases in zone $\mathrm{H} 2$.

In patients with chronic damage to the anterior part of the $\mathrm{JL}$, concomitant cartilage lesions were localized on the scapula predominantly in the S2 zone and on the articular surface of the humeral head in the $\mathrm{H} 3$ region (Fig. 7).

In patients with chronic lesions of the posterior part of the $\mathrm{JL}$, the location of concomitant cartilage defects on the scapula in sections S1, S3 was noted. At the humeral head, the defects were located in sections $\mathrm{H} 1, \mathrm{H} 2$ (Fig. 8).

It should also be noted that in this group of patients the highest among all groups is the percentage of damage to the cartilage of the humeral head $(81 \%)$. It should be noted again that the glenoid cavity cartilage suffers relatively equally in all groups (62-67\% of cases). On the other hand, the cartilage of the humeral head suffers in patients with damage of the back part of the $\mathrm{JL}$ almost twice as often as in the group of injuries of the front of the $\mathrm{JL}$ and almost 4 times more often than in the group of patients with damage to the upper part of the $\mathrm{JL}$.

The incidence of cartilage damage increases with time from injury (Fig. 9). 


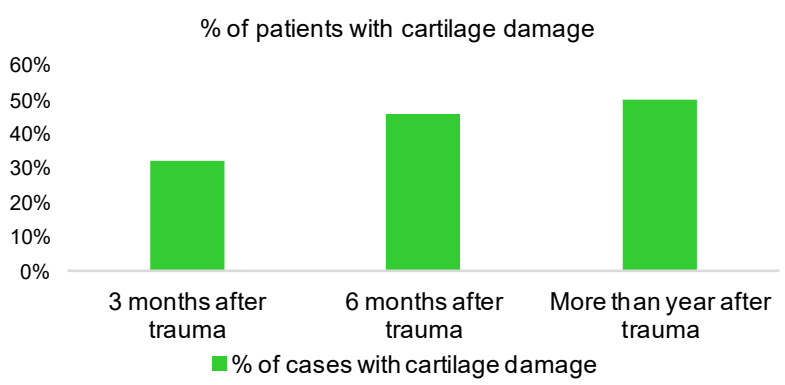

Fig. 9. Dependence of the incidence of cartilage damage on time from the moment of damage.

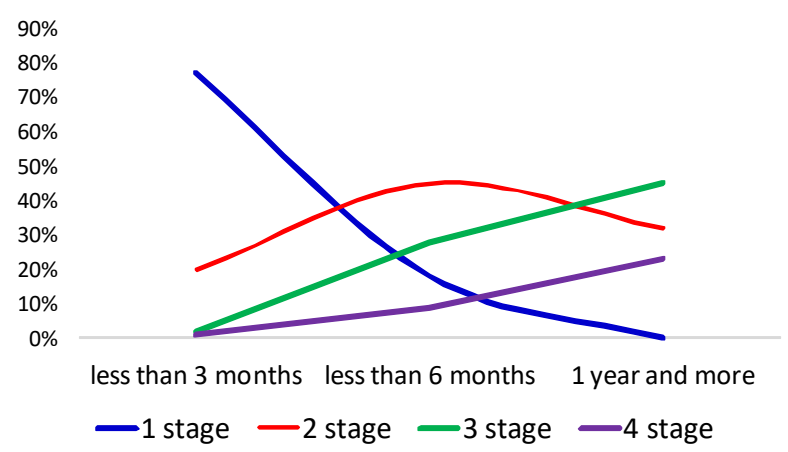

Fig. 10. Dependence of the depth of cartilage damage according to Outerbridge on time since the injury.

As can be seen from the data obtained, the likelihood of cartilage damage depends directly on the time elapsed since the injury.

The depth of cartilage damage also depends on the time elapsed since the injury (Fig. 10).

\section{Discussion}

The shoulder $\mathrm{JL}$ is an important anatomical structure in ensuring the normal functioning of the entire glenohumeral joint. It provides $[13,19,21]$ stability of the shoulder of the scapular joint due to a mechanical barrier to the displacement of the head and to create a "suction" effect. In addition, the complex of the glenohumeral ligaments $[2,12,20]$ and the tendons of the long head of the biceps $[1,5,11]$ are attached to the shoulder JL. The proprioceptive function of the $\mathrm{JL}$ and the function of synovial fluid distribution are important $[22,25]$. Due to the combination of $\mathrm{JL}$ functions together with the tendon of the long head of the biceps muscle and the muscles of the rotator cuff of the shoulder, the humerus at any position of

\section{References}

[1] Andrews, J. R., Carson J. R., W. G., \& Mcleod, W. D. (1985). Glenoid labrum tears related to the long head of the biceps. The American Journal of Sports Medicine, 13(5), 337-341. doi: $10.1177 / 036354658501300508$

[2] Bankart, A. B. (1938). The pathology and treatment of recurrent dislocation of the shoulder joint. British Journal of Surgery, 26(101), 23-29. https://doi.org/10.1002/bjs.18002610104

[3] Brophy, R. H., \& Marx, R. G. (2005). Osteoarthritis following the upper extremity contacts the glenoid cavity of the shoulder blade over a small area called "rotation point" [4, $8,10]$. Damage to any part of this complex biomechanical chain instantly leads to the appearance of chaotic movements of the humerus head within the glenoid cavity with the creation of foci of overload of cartilage and its subsequent destruction [8, 18].

As the results of our studies have shown, both the incidence of cartilage damage and the depth of such lesions increase with time. The more time has passed since the damage of the $\mathrm{JL}$, the more likely is the development of joint surface damage and the greater the degree of damage. These studies answer the question of the exclusive relationship of cartilage defects with primary trauma. Some of the cartilage damage may occur directly at the time of injury, as evidenced by the presence of such defects in patients at early follow-up. However, the increase in the frequency and depth of damage over time undoubtedly indicate that it is the disruption of the joint function due to the damage to the lip that causes the cartilage to collapse. This is logical because damage to the $\mathrm{JL}$ leads to the development of instability, loss of suction effect, impaired synovial fluid distribution function and loss of part of the proprioceptive properties of the capsule $[3,9$, 24].

Again, it should be noted that if the cartilage of the glenoid cavity suffers relatively equally in all groups $(62-67 \%$ of cases), the cartilage of the articular surface of the humeral head suffers the most in cases of damage to the back of the $\mathrm{JL}$ (almost twice as often as in the group of lesions of the anterior $\mathrm{JL}$ and almost 4 times more often than the group of patients with damage to the upper part of the $\mathrm{JL}$ ). Therefore, the need for early active surgical tactics in patients with $\mathrm{JL}$ damage to prevent the development and progression of SOA is unmistakable.

\section{Conclusions}

1. Damage to the shoulder $\mathrm{JL}$ is the cause of cartilage defects of the joint surfaces of the glenohumeral joint.

2. The incidence and severity of cartilage defects increase over time since the injury.

3. The worst prognosis of articular cartilage damage is characteristic of patients with damage to the back part of the JL.

4. Early active surgical tactics for the treatment of $\mathrm{JL}$ damage are necessary to prevent the deterioration of the joint surfaces and the prevention of SOA.

shoulder instability. Clinics in Sports Medicine, 24(1), 47-56. doi: 10.1016/j.csm.2004.08.010

[4] Cameron, M. L., Kocher, M. S., Briggs, K. K., Horan, M. P., \& Hawkins, R. J. (2003). The prevalence of glenohumeral osteoarthrosis in unstable shoulders. The American Journal of Sports Medicine, 31(1), 53-55. doi: 10.1177/ 03635465030310012001

[5] Choi, N. H., \& Kim, S. J. (2004). Avulsion of the superior labrum. 
Arthroscopy: The Journal of Arthroscopic \& Related Surgery, 20(8), 872-874. doi: 10.1016/j.arthro.2004.06.021

[6] Cole, B. J., Yanke, A., \& Provencher, M. T. (2007). Nonarthroplasty alternatives for the treatment of glenohumeral arthritis. Journal of Shoulder and Elbow Surgery, 16(5), S231S240. doi: 10.1016/j.jse.2007.03.011

[7] Elser, F., Braun, S., Dewing, C. B., \& Millett, P. J. (2010). Glenohumeral joint preservation: current options for managing articular cartilage lesions in young, active patients. Arthroscopy: The Journal of Arthroscopic \& Related Surgery, 26(5), 685696. doi: 10.1016/j.arthro.2009.10.017

[8] Fronek, J., Warren, R. F., \& Bowen, M. (1989). Posterior subluxation of the glenohumeral joint. The Journal of Bone and Joint Surgery. American Volume, 71(2), 205-216. PMID: 2918005

[9] Gerber, A., Lehtinen, J. T., \& Warner, J. J. (2003). Glenohumeral osteoarthritis in active patients: diagnostic tips and complete management options. The Physician and Sports Medicine, 31(4), 33-40. doi: 10.3810/psm.2003.04.312

[10] Hsu, H. C., Luo, Z. P., Stone, J. J., Huang, T. H., \& An, K. N. (2003). Correlation between rotator cuff tear and glenohumeral degeneration. Acta Orthopaedica Scandinavica, 74(1), 8994. doi: $10.1080 / 00016470310013725$

[11] Ilahi, O. A., Labbe, M. R., \& Cosculluela, P. (2002). Variants of the anterosuperior glenoid labrum and associated pathology. Arthroscopy: The Journal of Arthroscopic \& Related Surgery, 18(8), 882-886. doi: 10.1053/jars.2002.36119

[12] Kim, D. S., Yoon, Y. S., \& Yi, C. H. (2010). Prevalence comparison of accompanying lesions between primary and recurrent anterior dislocation in the shoulder. The American Journal of Sports Medicine, 38(10), 2071-2076. doi: 10.1177/ 0363546510371607

[13] Maffet, M. W., Gartsman, G. M., \& Moseley, B. (1995). Superior labrum-biceps tendon complex lesions of the shoulder. The American Journal of Sports Medicine, 23(1), 93-98. doi: 10.1177/036354659502300116

[14] McCarty III, L. P., \& Cole, B. J. (2005). Nonarthroplasty treatment of glenohumeral cartilage lesions. Arthroscopy: The Journal of Arthroscopic \& Related Surgery, 21(9), 1131-1142. doi: 10.1016/j.arthro.2005.06.023

[15] Outerbridge R. E. (1961). The etiology of chondromalacia patellae. The Journal of Bone and Joint Surgery. British Volume, 43(4), 752-757. PMID: 14038135
[16] Pettrone, F. A. (1994). Athletic Injuries of the Shoulder. McGrawHill.

[17] Provencher, M. T., Barker, J. U., Strauss, E. J., Frank, R. M., Romeo, A. A., \& Matsen III, F. A. (2011). Glenohumeral arthritis in the young adult. Instr. Course Lect., 60, 137-153. PMID: 21553769

[18] Siebold, R., Lichtenberg, S., \& Habermeyer, P. (2003). Combination of microfracture and periostal-flap for the treatment of focal full thickness articular cartilage lesions of the shoulder: a prospective study. Knee Surgery, Sports Traumatology, Arthroscopy, 11(3), 183-189. doi: 10.1007/ s00167-003-0363-x

[19] Snyder, S. J., Karzel, R. P., Del Pizzo, W., Ferkel, R. D., \& Friedman, M. J. (1990). SLAP lesions of the shoulder. Arthroscopy, 6(4), 274-279. doi: 10.1016/07498063(90)90056-j

[20] Terry, G. C., Friedman, S. J., \& Uhl, T. L. (1994). Arthroscopically treated tears of the glenoid labrum: Factors influencing outcome. The American journal of sports medicine, 22(4), 504-512. doi: $10.1177 / 036354659402200412$

[21] Terry, G. C., Hammon, D., France, P., \& Norwood, L. A. (1991). The stabilizing function of passive shoulder restraints. The American Journal of Sports Medicine, 19(1), 26-34. https:// doi.org/10.1177/036354659101900105

[22] Tibone, J. E., Fechter, J., \& Kao, J. T. (1997). Evaluation of a proprioception pathway in patients with stable and unstable shoulders with somatosensory cortical evoked potentials. Journal of Shoulder and Elbow Surgery, 6(5), 440-443. doi: 10.1016/s1058-2746(97)70050-8

[23] Tzannes, A., Paxinos, A., Callanan, M., \& Murrell, G. A. (2004). An assessment of the interexaminer reliability of tests for shoulder instability. Journal of Shoulder and Elbow Surgery, 13(1), 18-23. doi: 10.1016/S1058274603002453

[24] Weinstein, D. M., Bucchieri, J. S., Pollock, R. G., Flatow, E. L., \& Bigliani, L. U. (2000). Arthroscopic debridement of the shoulder for osteoarthritis. Arthroscopy: The Journal of Arthroscopic \& Related Surgery, 16(5), 471-476. doi: 10.2174/ 1874325000802010023

[25] Wolf, E. M., \& Siparsky, P. N. (2010). Glenoid avulsion of the glenohumeral ligaments as a cause of recurrent anterior shoulder instability. Arthroscopy: The Journal of Arthroscopic \& Related Surgery, 26(9), 1263-1267. doi: 10.1016/ j.arthro.2010.06.005

\section{ВПЛИВ ПОШКОДЖЕНЬ СУГЛОБОВОЇ ГУБИ ПЛЕЧА НА СТАН ХРЯЩА ПЛЕЧОЛОПАТКОВОГО СУГЛОБА Страфун С.С., Сергієнко P.O.}

Суглобова губа є анатомічною структурою плечолопаткового суглоба, однією з функцій якої є забезпечення стабільності плеча. Доведено, що нестабільність, пряма травма та хірургічні втручання будь-якого суглоба врешті-решт призводять до пошкодження хряща та розвитку остеоартрозу. Дотепер невідомо, чи впливають $і$ яким саме чином пошкодження суглобової губи впливають на стан хряща плечелопаткового суглоба. Мета дослідження - вивчення впливу пошкоджень суглобової губи плечелопаткового суглоба на стан хряща суглобових поверхонь. За період з 2006 до 2016 роки на базі ДУ "Інститут травматології і ортопедії АМН України", МЦ "Сучасна Ортопедія" м. Київ було проведено дослідження 467 пацієнтів. Використовували клінічну діагностику, МРТ діагностику, артроскопічну діагностику. Верифікацію факту та локалізацію ушкодження суглобової губи проводили під час артроскопічного дослідження. Локалізацію пошкоджень хряща розділяли на окремі ділянки на суглобовій западині лопатки та голівці плеча. Ступінь ураження хряща класифікували за Outerbridge. Кількісний аналіз отриманих результатів проводили за допомогою програми Microsoft Exсеl у зведених таблицях. З'ясували, що пошкодження суглобової губи плеча є причиною виникнення дефектів хряща суглобових поверхонь плечелопаткового суглоба. Частота та ступінь дефектів хряща збільшуються з часом від моменту травми. Найгірший прогноз розвитку пошкоджень суглобового хряща характерний для пацієнтів з ушкодженням задньої частини суглобової губи. Таким чином, ушкодження суглобової губи є вагомим чинником виникнення дефектів суглобового хряща плечелопаткового суглоба. Рання активна хірургічна тактика для лікування пошкоджень суглобової губи є необхідною для запобігання погіршення стану суглобових поверхонь та профрілактики остеоартрозу плечового суглоба.

Ключові слова: плечелопатковий суглоб, суглобова губа плеча, пошкодження хряща плечелопаткового суглоба. 


\section{ВЛИЯНИЕ ПОВРЕЖДЕНИЙ СУСТАВНОЙ ГУБЫ ПЛЕЧА НА СОСТОЯНИЕ ХРЯЩА ПЛЕЧЕЛОПАТОЧНОГО СУСТАВА}

\section{Страфун С.С., Сергиенко Р.A.}

Суставная губа является анатомической структурой плечелопаточного сустава, одной из функций которой является обеспечение стабильности плеча. Доказано, что нестабильность, прямая травма и хирургические вмешательства любого сустава приводят к повреждению хряща и развитию остеоартроза. До сих пор неизвестно, влияют ли и каким именно образом повреждения суставной губы влияют на состояние хряща плечелопаточного сустава. Цель исследования - изучение влияния повреждений суставной губы плечелопаточного сустава на состояние хряща суставных поверхностей. За период с 2006 до 2016 года на базе ГУ "Институт травматологии и ортопедии АМН Украины", МЦ "Современная Ортопедия" 2. Киев было проведено исследование 467 пациентов. Использовали клиническую диагностику, МРT диагностику, артроскопическую диагностику. Верификацию факта и локализацию повреждения суставной губы проводили во время артроскопического исследования. Локализацию повреждений хряща разделяли на отдельные участки на суставной впадине лопатки и головке плеча. Степень поражения хряща классифицировали по Outerbridge. Количественный анализ полученных результатов проводили с помощью программы Microsoft Excel в сводных таблицах. Выяснили, что повреждение суставной губы плеча является причиной возникновения дефектов хряща суставных поверхностей плечелопаточного сустава. Частота и степень десректов хряща увеличиваются со временем с момента травмы. Худший прогноз развития повреждений суставного хряща характерен для пациентов с повреждением задней части суставной губы. Таким образом, повреждения суставной губы являются весомым фрактором возникновения дефектов суставного хряща плечелопаточного сустава. Ранняя активная хирургическая тактика для лечения повреждений суставной губы необходима для предотвращения ухудшения состояния суставных поверхностей и профилактики остеоартроза плечевого сустава.

Ключевые слова: плечелопаточный сустав, суставная губа плеча, повреждение хряща плечелопаточного сустава. 